\title{
PROFITABILITY DETERMINANTS OF NEPALESE COMMERCIAL BANKS
}

\author{
DOI: 10.17261/Pressacademia.2020.1345 \\ PAP- V.12-2020(9)-p.40-45
}

\section{Bishnu Prasad Neupane}

Nepal Bank Limited, Deputy Manager, Kathmandu, Nepal.

bikalpa45@gmail.com, ORCID: 0000-0001-9074-7121

To cite this document

Neupane, B.P. (2020). Profitability determinants of nepalese commercial banks. PressAcademia Procedia (PAP), V.12, p.40-45.

Permanent link to this document: $\underline{\text { http://doi.org/10.17261/Pressacademia.2020.1345 }}$

Copyright: Published by PressAcademia and limited licensed re-use rights only.

\section{ABSTRACT}

Purpose- The purpose of this study is to examine the the key determinants of profitability of Nepalese commercial banks.

Methodology- This study employs descriptive statistics to describe the profitability of Nepalese banks and its determinants. Further, the degree of correlation among different indicators of profitability and its determinants has been assessed by calculating correlation coefficient. Finally, this study has adopted a panel data regression model (Fixed Effect Model and Random Effect Model) to investigate the determinants and their impact on profitability of Nepalese commercial banks.

Findings- The analysis reveals that the bank pofitability measured by ROA of Nepalese commercial banks is significantly affected by concentration ratio, banking sector development, GDP growth, inflation and exchange rate significantly in opposite direction rather it is not significantly affected by the internal factors like bank size, capital base, deposit, loan, off-balance sheet activities and number of branches. Another indicator of bank profitability; NIM is significantly affected only by capital adequacy, absolute number of branches and inflation rate. Conclusion- This study concluded that the profitability of Nepalese commercial banks measured by return on assets is significantly influenced by the external factors. Among external factors, industry specific factors have high degree of impact on return on assets whereas macroeconomic variables have quite a weak degree but significant impact on profitability of Nepalese commercial banks as measured by return on assets. Further, the profitability measured by net interest margin (NIM) is significantly influenced only by capital adequacy, absolute number of branches and annual inflation rate.

Keywords: Nepalese commercial banks, bank profitability, profitability determinants, internal and external determinants, ROA and NIM JEL Codes: C33, E44, G21

\section{INTRODUCTION}

Bank profitability is a key factor shaping financial development and economic growth (Osuagwu, 2014). The profitability of the banking sector of any country is important because the financial system of a country is largely based on banking system (Ali et al., 2011). Economies that have a profitable banking sector are better able to withstand negative shocks and contribute to the stability of the financial system (Athanasoglou et al., 2008). The profitable banks positively participate in the Gross Domestic Product (GDP) of a country. Therefore, it is essential to study the indicators that have any impact on the profitability of banks as the ever-changing social, legal and macroeconomic environment may cause these factors to change (Owoputi et al., 2014). Low profitability weakens the ability and willingness of banks to finance the wider economy (Garcia \& Trindade, 2019). Banks cannot function without being profitable, that not only helps them to cover the expenses and losses but also rewards the investors and depositors. Therefore, it is important to study the factors, which have an impact on the profitability of banks (Riaz \& Mehar, 2013).

\section{LITERATURE REVIEW}

There exists large number of studies that are conducted to analyze the determinants of banking profitability. Most of the studies classified the determinants of banking profitability as internal factors and external factors. Literature showed that various studies have used different indicators as measures and proxies of banks profitability. Studies like Jara-Bertin et al., (2014), Chowdhury \& Rasid (2016), Al-Homaidi et al. (2018) etc. used ROA, ROE, or both as bank profitability measures. In addition to ROA and ROE, Net Interest Margin (NIM) has also widely used as an indicator of bank profitability (Owoputi, 2014; Al-Homaidi et al., 2018; Islam \& Shohel Rana, 2019). ROA and ROE reflect how well bank management uses the bank's real investment resources, the NIM focuses on the profit earned on interest activities. Literature revealed that earning indicators Capital Strength and Liquidity are statistically significant variables whereas management efficiency, asset structure, asset quality and economic proxies are insignificant variables to describe bank profitability measured by NIM (Islam \& Shohel Rana, 2019).

Study of Eljelly (2013) and Madishetti \& Rwechungura (2013) showed that only the internal factors have the substantial impact on the profitability of the banks. Study of Acaravci \& Çalim (2013), Chowdhury \& Rasid (2016), Bougatef (2017), Sultan et al. (2020) used natural logarithm of total assets as a measure for bank size. Alper \& Anbar, (2011) and Masood \& Ashraf, (2012) reported a positive effect of banks size 
on banks' profitability. Whereas, Gul, Sehrish, Irshad, Faiza, Zaman, (2011) and Singh \& Sharma (2016) found a negative effect on banks' profitability. Similarly, the previous studies showed that the banks with a high capital ratio are considered to be insured against bankruptcy, to have access to cheap funds, to be more flexible in pursuing business opportunities and to have the ability to absorb any unexpected losses. Thus, higher profitability can be expected for these banks Athanasoglou et al., (2008), Flamini et al., (2009), Sufian, (2011), Ben Selma Mokni \& Rachdi, (2014), Olalere et al., 2017). But few studies like Saona, (2016) argued that well-capitalized banks are considered safer because they take less risk, and therefore produce lower returns and hence there exist negative relationship between profitability and capital adequacy.

Studies like Heffernan \& Fu, (2011), Sufian \& Kamarudin, (2012), Menicucci \& Paolucci, (2016) etc. showed that loans contribute to banks' profitability. On the other hand, studies like Kosmidou et al., (2006) and Heffernan \& Fu, (2011) claimed that the increase in loans could escalate the costs of funds and hence lead to a negative correlation between profitability and loans. Further the studies conducted by Chirwa, (2003), Saona, (2016), Menicucci \& Paolucci, (2016) etc. showed the evidence that deposits improve banks' profitability. But the studies like Gul et al., (2011), Akbas \& Karaduman, (2012), Tariq et al., (2014) etc. claimed that the lack of loan demand or poor management of the bank's liquidity could lead to a negative effect because these deposits would be costlier for banks in terms of the required branch networking and remuneration. Further, banks engage in off-balance sheet activities hoping to earn additional income to compensate for the decline of its earnings from traditional activities. Conversely, banks that are heavily involved in nontraditional activities are subject to higher risks which may lead to lower profitability (Al-Harbi, (2019). Studies like Valverde \& Fernández, (2007), Nguyen, (2011), Sufian, (2011), Petria et al., (2015) etc. found positive impact of off-balance sheet activities on bank profitability but the studies of Chen and Liao (2011), Rahman et al., (2015) etc. found negative relationship between them. By following the study of Al-Harbi, (2019), this study has used other operating income to total assets as a proxy of Off-balance sheet activities. In addition, Al-Homaidi et al., (2018) argued that the number of branches is the most significant bank-specific determinants that influence the banks' profitability.

Study conducted by Demirgüç-Kunt \& Huizinga (2000) supported structure-conduct performance theory, which indicates that high concentration is positively related to profitability. On the other hand, the efficient-market or efficient-structure hypothesis contradicts structure conduct-performance theory; specifically, the efficient-structure hypothesis suggests that firms with superior efficiency will obtain a large market share, and as consequence, the market will become more concentrated. Therefore, higher concentration does not necessarily imply market power, and consequently, the relationship between concentration and profitability does not have to be positive. This logic has been empirically verified by Ameur \& Mhiri (2013) which found a significant but negative relationship between concentration and profitability. Further, Demirgüç-Kunt \& Huizinga (1999) found a negative relation between profitability and banking sector development, especially in developing countries. On the other hand, large banking sectors bring more opportunities and reduce costs leading to higher profitability and margins. Ghosh (2016) reported a positive relationship between profitability (ROA) and industry size.

Large number of study used GDP as a macroeconomic factor and a common measure that is used to measure the aggregate economic activity within an economy (Masood \& Ashraf, 2012; Ongore \& Kusa, 2013; Pasiouras \& Kosmidou, 2007; Petria et al., 2015; Saona, 2016; Singh \& Sharma, 2016; Rani \& Zergaw, 2017). In this study, annual growth rate of real GDP has been used rather than using absolute value of real GDP. Further, Inflation rate has been widely used by prior studies of banks' profitability (Alper \& Anbar, 2011; Masood \& Ashraf, 2012; Jara-Bertin et al., 2014; Chowdhury \& Rasid, 2016). Further, Chowdhury \& Rasid, (2016) and Menicucci \& Paolucci (2016) suggested that foreign exchange rate is an important factor for banks' profitability.

\section{DATA AND METHODOLOGY}

To know the promising factors that affect the profitability of Nepalese banks, this study has used casual-comparative and descriptive type of research design to analyze the relationship between bank profitability and its determinants and to describe the actual happening in Nepalese commercial banks regarding the subject. Further, the study is based on quantitative information of 20 commercial banks for the period of 11 years (2010-2020) which is abstracted from different sources on the basis of their availability. To investigate the major determinants of bank's profitability of Nepalese commercial banks, quantitative data from secondary sources has been abstracted. For the purpose, data with yearly frequency has been used in this study. Banking and Financial Statistics issued by NRB and the financial statements of banks from their websites are major sources of data. Further, data issued by Ministry of Finance and reports of World Bank also used as a source of data for this study.

Major factors that can affect the bank profitability of Nepalese commercial have been selected on judgmental basis. For the study purpose, return on assets (ROA) and net interest margin (NIM) have been used as the indicators of bank profitability. Further, the factors that might affect the bank profitability have been categorized as internal and external factors. Study used bank size (LNAS), Capital adequacy (CAD), Loans (LOAN), Deposits (DEP), Off-balance sheet activities (OBS) and number of branches (BRN) as internal factors of bank profitability. Similarly, bank specific variables; n-Bank Concentration Ratio (CONC) and Banking sector development (BSD) and macro-economic variables; Annual real GDP (GDP), Annual inflation rate (INF) and Exchange rate (EXR) have been used as the external determinants of bank profitability.

As the tool of data analysis, this study has used descriptive statistics to describe the profitability of Nepalese banks and its determinants. Further, the degree of correlation among different indicators of profitability and its determinants has been assessed by calculating correlation coefficient. Finally, this study has adopted a panel data regression model (Fixed Effect Model and Random Effect Model) to investigate the determinants and their impact on profitability of Nepalese commercial banks. To decide the suitable model between Fixed Effect Model and Random Effect Model, different test has been performed. In this study, fixed effects are tested by the $\mathrm{F}$ test, while random effects are examined by the Lagrange multiplier (LM) test (Breusch \& Pagan, 1980). Further, Husman specification test has been conducted to select appropriate model between random effect and fixed effect.

For the purpose of empirical analysis of determinants of profitability of Nepalese commercial banks, the following model is specified:

$$
\pi_{i t}=\alpha+\beta_{1} I F_{i t}+\beta_{2} E F_{i t}+U_{i t}
$$

Here, $\pi_{i t}$ denotes the profitability level of bank $\mathrm{i}$ at time $\mathrm{t}$, IF and $\mathrm{EF}$ are internal factors and internal factors respectively and $U_{i t}$ is the error term. 


\section{FINDINGS}

Pearson correlation coefficients between the variables advocate that the bank profitability measured by ROA has significant positive correlation with capital adequacy ratio, off balance sheet activities and GDP growth rate where as it has significant negative correlation with inflation rate. Further, ROA has no significant correlation with size, loan, deposit, number of branches, concentration ratio, banking sector development and exchange rate. Another indicator of profitability NIM is significantly correlated only with bank size, loan, deposit and branch number in same direction. Therefore, correlation analysis concluded that bank profitability measured by ROA can significantly be influenced by capital base, offbalance sheet activities, growth rate of real GDP and inflation rate whereas the profitability measured by NIM can be significantly affected by size of the bank, loan, deposit and absolute number of branches.

In this study, stationarity of each variable have been checked by using panel unit root test. Result of unit root test revealed that ROA, ROE, CAD, OBSA, CONC and GDP growth do not have unit root (hence are stationary) in level and hence are I( 0 ) variables whereas rest of the variables; SIZE, DEPOSIT, LOAN, BRN, BSD and INF have unit root and hence are non-stationary in level but are stationary in first difference and hence are I(1) variables.

\subsection{Regression Analysis}

For the analysis purpose, this study seeks for suitable panel regression model among pooled OLS, Fixed Effect Model and Random Effect Model. Applying appropriate model avoid biased and spurious result (Staikouras \& Wood, 2011). Fixed effects have been tested by the $F$ test, while random effects are examined by (Breusch \& Pagan's (1980) Lagrange Multiplier (LM) test. The former compares a fixed effect model and OLS to see how much the fixed effect model can improve the goodness-of-fit, whereas the latter contrast a random effect model with OLS. Further, Hausman specification test (Hausman, 1978) has been applied to compare the random effect model to its fixed counterpart (Hun, 2011). Under Hausman test, if the null hypothesis that the individual effects are uncorrelated with the other regressors is not rejected, a random effect model is favored over its fixed counterpart.

Testing a Fixed Effect (F-test) shows that there is a significant fixed effect or significant increase in goodness-of-fit in the fixed effect model; therefore, the fixed effect model is better than the pooled OLS. Similarly, Testing Random effect model (LM-test) also suggests that there is a significant random effect in the panel data, and that the random effect model is able to deal with heterogeneity better than does the pooled OLS. Finally, Hausman specification test to compare between fixed and random effect models shows that Fixed Effect Model is appropriate when ROA is taken as an indicator of profitability whereas Random Effect Model as an appropriate model for analysis when NIM is used as an indicator of bank profitability. The result of Hausman test has been presented in table 1 . Table 1 presents the result of Hausman test. Panel-A shows the result of Hausman test for model in which ROA is used as a dependent variable and Panel-B shows the result of Hausman-test for model in which NIM is used as a dependent variable.

Table 1: Hausman Test

\begin{tabular}{|c|c|c|c|}
\hline \multicolumn{2}{|c|}{ Panel-A: ROA as profitability } & \multicolumn{2}{|c|}{ Panel-B: NIM as profitability } \\
\hline Chi square & 199.08 & Chi square & 3.26 \\
\hline \multicolumn{2}{|l|}{ Prob $>$ Chi square $=$} & \multicolumn{2}{|c|}{ Prob $>$ Chi square $=0.9868$} \\
\hline \multicolumn{2}{|c|}{ FEM is appropriate } & \multicolumn{2}{|c|}{ REM is appropriate } \\
\hline
\end{tabular}

In Panel-A, value of chi-square is significant at $5 \%$ level of significance and hence suggest that Fixed Effect Model is appropriate. In contrast to this, Panel-B revealed that the value of chi-square is insignificant at $5 \%$ level of significance and hence suggest the Random Effect Model as an appropriate model for analysis. Therefore, this study has applied fixed effect model to analyze the determinants of bank profitability if it is measured by ROA and random effect model to analyze the determinants when the profitability is measured by NIM. Table 2 presents the summary result of model estimation. In table, Panel-A is the result of fixed effect model estimation when profitability is measured by ROA and Panel-B is the result of random effect model estimation when profitability is measured by NIM.

Table 2: Model Estimation Results Summary

\begin{tabular}{|c|c|c|c|c|c|c|c|c|}
\hline \multicolumn{5}{|c|}{ Panel-A: ROA } & \multicolumn{4}{|c|}{ Panel-B: NIM } \\
\hline & Coef. & Std. Err. & $\mathrm{t}$-value & $p$-value & Coef. & Std. Err. & $t$-value & $p$-value \\
\hline Constant & 0.3721 & 0.0717 & 5.19 & 0.0000 & 0.0515 & 0.0517 & 1.00 & 0.3190 \\
\hline Size & 0.0122 & 0.0121 & 1.01 & 0.3140 & -0.0096 & 0.0087 & -1.10 & 0.2730 \\
\hline CAD & -0.0150 & 0.0226 & -0.66 & 0.5070 & 0.0410 & 0.0148 & 2.76 & 0.0060 \\
\hline Deposit & -0.0067 & 0.0107 & -0.62 & 0.5330 & -0.0069 & 0.0076 & -0.90 & 0.3660 \\
\hline Loan & 0.0115 & 0.0071 & 1.62 & 0.1060 & 0.0046 & 0.0051 & 0.89 & 0.3710 \\
\hline OBSA & 0.2581 & 0.1977 & 1.31 & 0.1930 & 0.0771 & 0.1341 & 0.57 & 0.5650 \\
\hline BRN & 0.0000 & 0.0000 & 0.22 & 0.8250 & 0.0001 & 0.0001 & 2.10 & 0.0360 \\
\hline CONC & -0.8308 & 0.1617 & -5.14 & 0.0000 & -0.0425 & 0.1166 & -0.36 & 0.7160 \\
\hline BSD & -0.2125 & 0.0563 & -3.78 & 0.0000 & -0.0188 & 0.0408 & -0.46 & 0.6460 \\
\hline GDP & -0.0032 & 0.0008 & -3.83 & 0.0000 & 0.0001 & 0.0006 & 0.04 & 0.9690 \\
\hline INF & -0.0008 & 0.0003 & -2.30 & 0.0230 & 0.0009 & 0.0002 & 3.44 & 0.0010 \\
\hline EXR & -0.0008 & 0.0002 & -4.89 & 0.0000 & -0.0001 & 0.0001 & -0.82 & 0.4130 \\
\hline \multicolumn{5}{|c|}{ F-statistics $=6.53$, Prob $>F=0.0000$} & \multicolumn{4}{|c|}{ Wald chi-square $=59.40$, Prob $>$ chi-square $=0.0000$} \\
\hline \multicolumn{5}{|c|}{ R-squared $=0.5370$} & \multicolumn{4}{|c|}{ R-squared $=0.2665$} \\
\hline LR Test & & & & & $=86.89$, Prob & uare $=0.0$ & & \\
\hline
\end{tabular}

As per the result presented in Panel A of table 2, F-statistic is significant (p-value is less than 0.05 ) and hence the fixed effect model is significant for estimating ROA of a bank. Further, the independent variables applied in this study can describe 53.70 percent variation in ROA of the bank which is advocated by the value of R-square. According to the result of Panel-A, ROA of Nepalese commercial bank is not significantly affected by the internal factors like bank size, capital base, deposit, loan, off-balance sheet activities and number of branches. Therefore the result of 
this study contract with the study of Eljelly (2013) and Madishetti \& Rwechungura (2013) which concluded that only the internal factors have the substantial impact on the profitability of the banks. Further, the result of this study contradict with the result of Pradhan \& Shrestha (2018) who showed that all the bank specific factors are found to be significant factors affecting the bank performance. Result showed that ROA of a bank is positively influenced by size of the bank, loan, off-balance sheet activities and absolute number of branches but their impact seems insignificant. Further, ROA is negatively influenced by capital base and deposit but their impact also is insignificant. The result of this study could not verify the evidence of the economies of scale theory, negative impact of credit portfolio volume and weak asset quality, and positive impact of greater bank activity diversification with bank profitability measured by ROA found by the study of Gwachha (2019) in Nepalese banking. Though the significant factor of banking profitability seems alike, the direction of impact of external factors like market share (here represented by concentration ratio) and GDP also contradict with the study of Pradhan (2018) in Nepalese context.

Panel-B of table 2 is the estimation result of random effect model in which NIM has been used as an indicator of bank profitability. Statistically significant Wald chi-square (i.e. p-value is less than 0.05) indicates that the model is significant and best fit. Further, the variables that affect bank profitability applied in this model can describe only 26.65 percent variability in NIM. Further, the statistically significant Chibar-square value of likelihood ratio (LR) test confirmed the significance of random effect. Estimation result revealed that the NIM is significantly affected only by capital adequacy, absolute number of branches and inflation rate as their p-values are lower than 0.05 . Though their impact seems statistically significant, degree of impact is very nominal as signified by their coefficient values. Though the NIM is positively influenced by loan, off-balance sheet activities, and GDP growth rate and negatively influenced by bank size, deposit, concentration ratio, banking sector development and exchange rate, their impact on NIM are insignificant in Nepalese commercial banks.

\section{CONCLUSION}

Study of analyzing the determinants of commercial bank profitability in Nepal shows that only external factors shape the size of bank profitability as measured by return on assets. Among external factors, industry specific i.e. concentration and banking sector development have high degree of impact on return on assets whereas macroeconomic variables i.e. GDP growth, inflation rate and exchange rate have quite a weak degree but significant impact on profitability of Nepalese commercial banks as measured by return on assets. Further, the profitability of Nepalese commercial banks measured by net interest margin (NIM) is shaped only by few variables included in this study. Capital adequacy, absolute number of branches and annual inflation rate significantly determine the level of net interest margin of Nepalese commercial banks.

\section{REFERENCES}

Akbas, H. E., \& Karaduman, H. A. (2012). The effect of firm size on profitability: An empirical investigation on Turkish manufacturing companies. European Journal of Economics, Finance and Administrative Sciences, 55.

Al-Harbi, A. (2019). The determinants of conventional banks profitability in developing and underdeveloped OIC countries. Journal of Economics, Finance and Administrative Science, 24(47), 4-28. https://doi.org/10.1108/JEFAS-05-2018-0043

Al-Homaidi, E. A., Tabash, M. I., Farhan, N. H. S., \& Almaqtari, F. A. (2018). Bank-specific and macro-economic determinants of profitability of Indian commercial banks: A panel data approach. Cogent Economics and Finance, 6(1), 1-26. https://doi.org/10.1080/23322039.2018.1548072

Ali, K., Akhtar, M. F., \& Ahmed, H. Z. (2011). Bank-Specific and Macroeconomic Indicators of Profitability - Empirical Evidence from the Commercial Banks of Pakistan. International Journal of Business and Social Science, 2(6), 235-242.

Alper, D., \& Anbar, A. (2011). OKUNDU_02.03.2018_GÜZEL_Bank Specific and Macroeconomic Determinants of Commercial Bank Profitability: Empirical Evidence from Turkey. Business \& Economics Research Journal, 2(2), 139-152.

Ameur, I. G. Ben, \& Mhiri, S. M. (2013). Explanatory Factors of Bank Performance Evidence from Tunisia. International Journal of Economics, Finance and Management, 2(1).

Athanasoglou, P. P., Brissimis, S. N., \& Delis, M. D. (2008). Bank-specific, industry-specific and macroeconomic determinants of bank profitability. Journal of International Financial Markets, Institutions and Money, 18(2), 121-136. https://doi.org/10.1016/j.intfin.2006.07.001

Baltagi, B. (2005). Econometric analysis of panel data. In Vasa.

Ben Selma Mokni, R., \& Rachdi, H. (2014). Assessing the bank profitability in the MENA region. International Journal of Islamic and Middle Eastern Finance and Management, 7(3). https://doi.org/10.1108/imefm-03-2013-0031

Bougatef, K. (2017). Determinants of bank profitability in Tunisia: does corruption matter? Journal of Money Laundering Control, 20(1). https://doi.org/10.1108/JMLC-10-2015-0044

Breusch, T. S., \& Pagan, A. R. (1980). The Lagrange Multiplier Test and its Applications to Model Specification in Econometrics. The Review of Economic Studies, 47(1). https://doi.org/10.2307/2297111

Chirwa, E. W. (2003). Determinants of commercial banks' profitability in Malawi: A cointegration approach. Applied Financial Economics, 13(8). https://doi.org/10.1080/0960310022000020933

Chowdhury, M. A. F., \& Rasid, M. E. S. M. (2016). Determinants of Performance of Islamic Banks in GCC Countries: Dynamic GMM Approach. In Advances in Islamic Finance, Marketing, and Management. https://doi.org/10.1108/978-1-78635-899-820161005

Demirgüç-Kunt, A., \& Huizinga, H. (1999). Determinants of commercial bank interest margins and profitability: Some international evidence. World Bank Economic Review, 13(2), 379-408. https://doi.org/10.1093/wber/13.2.379

Demirgüç-Kunt, A., \& Huizinga, H. (2000). Financial Structure and Bank Profitability. International Journal of Cooperative Information Systems. https://doi.org/10.1596/1813-9450-2430 
Eljelly, A. M. A. (2013). Internal and external determinants of profitability of Islamic banks in Sudan: Evidence from panel data. Afro-Asian Journal of Finance and Accounting, 3(3). https://doi.org/10.1504/AAJFA.2013.054424

Flamini, V., Schumacher, L., \& McDonald, C. A. (2009). The Determinants of Commercial Bank Profitability in Sub-Saharan Africa. IMF Working Papers. https://doi.org/10.5089/9781451871623.001

Garcia, M. T. M., \& Trindade, M. J. (2019). Determinants of banks' profitability in Angola. African Journal of Economic and Management Studies, 10(1). https://doi.org/10.1108/AJEMS-06-2018-0161

Ghosh, S. (2016). How Do Banks Influence Firm Capital Structure? Journal of Corporate Accounting \& Finance, 27(6). https://doi.org/10.1002/jcaf.22189

Gul, S., Irshad, F., \& Zaman, K. (2011). Factors Affecting Bank Profitability in Pakistan. Romanian Economic Journal, 3(2).

Gwachha, K. P. (2019). Bank specific and macroeconomic determinants of banking profitability in Nepal Research methodology. SEBON Journal, VII(May 2019), 120-129.

Hausman, J. A. (1978). Specification Tests in Econometrics EC ON ME R C A VOLUME 46 NOVEMBER, 1978 NUMBER 6 SPECIFICATION TESTS IN ECONOMETRICS. Econometrica, 46(6).

Hun, M. P. (2011). Practical Guides To Panel Data Modeling : A Step by Step. Public Management and Public Analysis Program, 1-53.

Islam, S., \& Shohel Rana, M. (2019). Determinants of Bank Profitability: Evidence from Commercial Banks of Bangladesh. Journal of Asian Business Strategy, 9(2), 174-183. https://doi.org/10.18488/journal.1006.2019.92.174.183

Jara-Bertin, M., Arias Moya, J., \& Rodríguez Perales, A. (2014). Determinants of bank performance: evidence for Latin America. Academia Revista Latinoamericana de Administracion, 27(2). https://doi.org/10.1108/ARLA-04-2013-0030

Kosmidou, K., Pasiouras, F., Doumpos, M., \& Zopounidis, C. (2006). Assessing performance factors in the UK banking sector: A multicriteria methodology. Central European Journal of Operations Research, 14(1). https://doi.org/10.1007/s10100-006-0158-5

Kosmidou, Kyriaki. (2007). The determinants of banks' profits in Greece during the period of EU financial integration. Managerial Finance, 34(3). https://doi.org/10.1108/03074350810848036

Madishetti, S., \& Rwechungura, K. A. (2013). A sian R esearch C onsortium Determinants of Bank Profitability in a Developing Economy : Empirical Evidence from Tanzania. 3(11).

Masood, O., \& Ashraf, M. (2012a). Bank-specific and macroeconomic profitability determinants of Islamic banks: The case of different countries. Qualitative Research in Financial Markets, 4(2-3). https://doi.org/10.1108/17554171211252565

Masood, O., \& Ashraf, M. (2012b). Bank-specific and macroeconomic profitability determinants of Islamic banks. Qualitative Research in Financial Markets, 4(2/3). https://doi.org/10.1108/17554171211252565

Menicucci, E., \& Paolucci, G. (2016). The determinants of bank profitability: empirical evidence from European banking sector. In Journal of Financial Reporting and Accounting (Vol. 14, Issue 1). https://doi.org/10.1108/jfra-05-2015-0060

Nguyen, T.-M. (2011). Learning to communicate in a globalized world: To what extent do school textbooks facilitate the development of intercultural pragmatic competence? In RELC Journal (Vol. 42, Issue 1). https://doi.org/10.1177/0033688210390265

Olalere, O. E., Bin Omar, W. A., \& Kamil, S. (2017). Bank Specific and Macroeconomic Determinants of Commercial Bank Profitability: Empirical Evidence from Nigeria. International Journal of Finance \& Banking Studies (2147-4486), 6(1). https://doi.org/10.20525/ijfbs.v6i1.627

Ongore, V. O., \& Kusa, G. B. (2013). International journal of economics and financial issues. International Journal of Economics and Financial Issues, 3(1), 237-252. http://www.econjournals.com/index.php/ijefi/article/view/334

Osuagwu, E. S. (2014). Determinants of Bank Profitability in Nigeria. International Journal of Economics and Finance, 6(12), 1-20. https://doi.org/10.5539/ijef.v6n12p46

Owoputi, J. A. (2014). BANK SPECIFIC, INDUSTRY SPECIFIC AND MACROECONOMIC DETERMINANTS OF BANK PROFITABILITY IN NIGERIA Olawale Femi Kayode, Postgraduate student Felix Ademola Adeyefa, Postgraduate student. In European Scientific Journal (Vol. 10, Issue 25).

Owoputi, J. A., Kayode, O. F., \& Adeyefa, F. A. (2014). Bank specific, industry specific and macroeconomic determinants of bank profitability in Nigeria. European Scientific Journal, 10(25).

Pasiouras, F., \& Kosmidou, K. (2007). Factors influencing the profitability of domestic and foreign commercial banks in the European Union. Research in International Business and Finance, 21(2). https://doi.org/10.1016/j.ribaf.2006.03.007

Petria, N., Capraru, B., \& Ihnatov, I. (2015). Determinants of Banks' Profitability: Evidence from EU 27 Banking Systems. Procedia Economics and Finance. https://doi.org/10.1016/s2212-5671(15)00104-5

Pradhan, R. S. (2018). Bank Specific and Macroeconomic Determinants of Bank Profitability: A Case of Nepal. SSRN Electronic Journal, 1-11. https://doi.org/10.2139/ssrn.2793484

Pradhan, R. S., \& Shrestha, R. (2018). Impact of Bank Specific and Macroeconomic Variables on the Performance of Commercial Banks of Nepal. SSRN Electronic Journal, 47, 91-110. https://doi.org/10.2139/ssrn. 2793530

Rahman, M. M., Hamid, M. K., \& Khan, M. A. M. (2015). Determinants of Bank Profitability: Empirical Evidence from Bangladesh. International Journal of Business and Management, 10(8), 135-150. https://doi.org/10.5539/ijbm.v10n8p135 
Rani, D. M. S., \& Zergaw, L. N. (2017). Bank Specific , Industry Specific and Macroeconomic Determinants of Bank Profitability in Ethiopia Issn : 2278-6236. International Journal of Advanced Research in Management and Social Sciences, 6(3).

Raza, H., Saeed, A., \& Hena, S. (2019). Determinants of Profitability in Banking Sector: An Evidence from Pakistan. European Scientific Journal ESJ, 15(7). https://doi.org/10.19044/esj.2019.v15n7p35

Riaz, S., \& Mehar, A. (2013). The impact of Bank Specific and Macroeconomic Indicators on the Profitability of Commercial banks. The Romanian Economic Journal, XVI(47), 91-110.

Saona, P. (2016). Intra- and extra-bank determinants of Latin American Banks' profitability. International Review of Economics and Finance, 45 , 197-214. https://doi.org/10.1016/j.iref.2016.06.004

Singh, A., \& Sharma, A. K. (2016). An empirical analysis of macroeconomic and bank-specific factors affecting liquidity of Indian banks. Future Business Journal, 2(1). https://doi.org/10.1016/j.fbj.2016.01.001

Staikouras, C. K., \& Wood, G. E. (2011). The Determinants Of European Bank Profitability. International Business \& Economics Research Journal (IBER), 3(6). https://doi.org/10.19030/iber.v3i6.3699

Sufian, F. (2011). Profitability of the Korean Banking Sector: Panel Evidence on Bank-Specific and Macroeconomic Determinants. Journal of Economics and Management, 7(1), 43-72.

Sufian, F., \& Kamarudin, F. (2012). Bank-Specific and Macroeconomic Determinants of Profitability of Bangladesh's Commercial Banks. Bangladesh Development Studies, 35(4), 1-29.

Sultan, K., Rzgar Ahmed, R., Mohammad Ameen, F., \& Singh, M. (2020). THE EFFECT OF MACROECONOMIC \& BANK SPECIFIC FACTORS ON BANKS PROFITABILITY: AN EMPIRICAL EVIDENCE FROM BANKING INDUSTRY OF PAKISTAN. Humanities \& Social Sciences Reviews, 8(3). https://doi.org/10.18510/hssr.2020.8368

Tariq, W., Usman, M., Mir, H. Z., Aman, I., \& Ali, I. (2014). Determinants of Commercial Banks Profitability: Empirical Evidence from Pakistan. International Journal of Accounting and Financial Reporting, 1(1). https://doi.org/10.5296/ijafr.v4i2.5939

Valverde, S. C., \& Fernández, F. R. (2007). The determinants of bank margins in European banking. Journal of Banking and Finance, 31 